\title{
Art and Design Education in an Intoleranized- Tolerant Society:
}

\author{
The Future Challenges and Strategies
}

\author{
Yasraf Amir Piliang* \\ Institut Teknologi Bandung \\ Bandung, Indonesia \\ *yappiliang@gmail.com
}

\begin{abstract}
Tolerance is one of central issues in today's social and political life in Indonesia. Although multidimensional and complicated in its practice, it is one of fundamental cultural roots and national core identities. As a multicultural nation-state which consists of various ethnic, racial and religious groups, tolerance is an important cultural root manifested in various social, political, cultural, religious forms, particularly art forms. Various art forms like architecture, puppet shows, ornaments, clothing, music, and other performing arts, were historically created on the basis of ethical principle of tolerance. Here, art is a media for strengthening social cohesion through which the spirit of tolerance is inherited from one generation to another. Yet, the greater and greater dominance of political power in shaping everyday cultural life has a tremendous impact on social life, particularly on the fading of the sense of tolerance. The political system that celebrates individualism and egocentrism has systematically eroded the spirit of tolerance to be replaced by antagonistic and conflicted forms of social life. The end result is a divided society with the congenital value of hostility, antagonism, and enmity. In this antagonistic social situation, there has been a great challenge for art in general, and art education in particular, to take a certain role in an attempt to rebuild a new construction of tolerance in contemporary informational-digital society. In art education, there are at least three locus of tolerance that could be developed: 1) tolerance in art processes, 2) tolerance through art events, and 3) tolerance in art work.
\end{abstract}

Keywords-tolerance, art education, multicultural art, divided society

\section{INTRODUCTION}

Discussion about tolerance-as one of central issues in Indonesia as a plural and multicultural society-cannot be separated from other different but related issues about pluralism, multiculturalism, political reformation and democratization. Since the process of political reformation in 1998 s, the issue about tolerance-in its relation to the process of democratization in general, and the condition of plurality and multiculturality in particular-has become one of the main problems in everyday social life, as a manifestation of political freedom in a new democratic society. Yet, the political reformation has been incapable of creating a better situation for the dissemination of the spirit of tolerance and better life. In contrast, social relations among different religious, ethnic and racial groups have become worse and worse, as a result of the over-determination of political power in shaping everyday social life.

Tolerance is one of fundamental ideas or "cultural roots" in the state ideology of Pancasila (Five Pilars), and the national motto, Bhinneka Tunggal Ika that contains the idea of "uni(ci)ty in diversity" [1]. If we discuss nation as a "container", we talk about "unity" as the condition of the oneness of nation, which is represented in several symbols of unity: flag, emblem, national anthem, etc. On the other hand, if we discuss nation as "contents of the container", we talk about 'unicity,' as an assemblage of different national elements, which cannot be represented in a single conept or identity. Here, national identity is not expressed in a single modality, but multi-modalities. National identity is the assemblage of these multi-modalities represented in the motto uni(ci)ty in diversity. The core idea of uni(ci)ty in diversity is the value of harmonious life, which is shared by several ethnic groups in Indonesia, although in different manifestations. In Javanese culture this is related to the value of urmat (honor) that shapes the Javanesse personality as a person who value harmony, social conformity and avoid conflict [2].

"Gotong royong" (work in common) is another core idea of Pancasila, which is substantially related to the idea of tolerance. It is not only a cultural tradition of working together in executing certain task in the condition of absence of any personal interest, but also a fundamental world view (Lebenswelt). Koentjaraningrat defines 'gotong royong' as "...the mobilization of human power without payment for a certain project or work that has a public benefit or useful for development" [3]. Here, gotong royong is not only a physical tendency of working together to perform certain tasks, but a way of life of the society organized in the model of paguyuban (Gemeinschaft). It is the manifestation of a communal form of life, that is, the life without pamrih (reward). In gotong royong there is no expectation of personal interest, reward, or profit, as the manifestation of the harmonious form of life (rukun) [4]. 
Another fundamental principle related to the idea of tolerance and harmony is musyawarah (parley), as an indigenous model of public open discussion to solve any conflicts or disputes in order to come to a mufakat (consensus) [5]. As two fundamental principles, gotong royong and permusyawaratan are shared by different ethnic groups in Indonesia, albeit manifested in different forms. In Bali, the value of gotong royong is manifested in the principle of subak, which is a traditional institution in managing the watering system of rice field so that water could be collectively utilized. In West Java, it is manifested in collective house building. In Dayak tribe, it is manifested in collective tradition of clearing [5]. In Minangkabau tradition, it is manifested in the aphorism of "barek samo dipikua, ringan samo dijinjiang" (lets carry heavy things together on our shoulder, lets carry light things together by our hands), as the manifestation of the spirit of togetherness [6].

The principle of tolerance could also be seen in cultural wisdom of Manado, in which the teaching about tolerant and harmonious form of life could be read in local slogan of "torang samua basudara" (all of us are brothers). The slogan contains a moral wisdom of seeing all men as brothers, whose existences have to be equally recognized as human beings with whom anyone could work together in all positive activities. Here, religious, ethnic, and racial differences are not an obstacle in disseminating this positive and constructive value in the whole society, through which a harmonious and peaceful society could be structurally built. As a moral teaching, the slogan torang samua basudara, is a moral principle that emphasizes process rather than the end result, through which tolerance is seen as a never ended process that has to be incessantly renewed or rebuilt [7].

The similar spirit of tolerance can also be seen in Ambonese principle of pela gandong, as a local wisdom related to social relations among different ethnic and religious groups in Ambon. More than as genealogical relation or bond, pela is a social bond beyond the religious or ethnic borders. Pelagandong is a union between one region and others in the Ambon-Lease islands and several regions in Seram Island. The basis of union is genealogical or consanguinity, for which a kind of verbal or written agreement or consensus is made, through which both parties promise to submit the agreement as a legal standing in the future social encounters. Yet, the strong political intervention into the everyday life of the Ambonese, particularly horizontal ethnic-religious conflict in 1999-2000, has made pela gandong as a strong local ethic and wisdom sealed by strong political energies controlling the harmonious and peaceful Ambonese [8].

This spirit of tolerance can also be identified in the performing art of wayang (traditional Javanese puppet). In this kind of art, the role of Wali Songo (The Nine Spiritual Guardian), particularly Sunan Kali Jaga, is highly central in creating and designing new ideas of wayang, based on previous traditional design. He tried to incorporate elements of Islamic doctrine combined harmoniously with some noble values of Javanese culture. Tolerance was regarded as an important part of cultural strategies of wayang, because of the plural character of Javanese society. Here, wayang as a creative medium adopted from Hindu-Buddha tradition, was taken as a medium to strengthen social bond and brotherhood among plural Javanese society, by adopting the Hindu-Buddha tradition incorporated with some Islamic doctrines. Elements of HinduBuddha traditions were maintained as a manifestation of cultural respect and tolerance to this tradition [9].

In Minangkabau society, the spirit of tolerance is also manifested in the local philosophy of merantau (emigration). Merantau is not a social deterritorialization aimed for dominating a new land - as in the Western colonial concepts of new foundland, new frontier and utopia-as a new founded territory. The proverb di ma bumi dipijak, di sinan langik dijunjung (where the earth is trampled, the sky is upheld) means that the new land is not a seized land, but a temporary place for self-development, where the local culture and customs are inclusively respected. It is a culture that highly respects others in terms of differences and pluralism. One of the cultural characteristics of the people of Minangkabau is their habit to emigrate from their mother land to other places in Indonesia even to all over the world. In the new land, they try to commit to the basic principle of tolerance: di ma bumi dipijak, di sinan langik dijunjung as the basic manifestation of tolerance [10].

This spirit of tolerance was also manifested in various traditional art and architectural expressions. This visual manifestation of tolerance, for example, could be seen in several architectural ornament of mosque, particularly in the northern coastal areas of Java. The aesthetic manifestation of ornaments of the mosques had originated from pre-Islamic (Java, Hindu-Buddha, China) ornamental traditions (mytological forms, organic forms, flora, fauna) which were creatively combined with Islamic ornamental traditions (geometry, Arabesque, calligraphy) to produce harmonius aesthetic expressions. The ornament and motives have not only aesthetic function, but also symbolic function related to preIslamic and Islamic cultural values and beliefs. Seen from inter-cultural perspectives, these ornaments are manifestation of the spirit of tolerance as a basic value of multicultural society [11].

It could be argued from the above discussion that tolerance is the fundamental principle shared by various ethnic, racial and religious groups in Indonesia, as basic ways in building a harmonious form of life. Nevertheless, the dominance of political power in shaping cultural life since Reformation in 1998 has gradually created a social life marked by various form of intolerant behavior and expressions culminated in the division of society, which are separated into two large and conflicting groups based on their political aspirations. In art practice and art education, in particular, this power of intolerance has been manifested in various conflicting art forms and discourses. In other words, art, art practice and art education themselves is structurally "trapped" in this scheme of intolerance and 'great divide'. 


\section{THEORETICAL FRAMEWORK}

In terms of ethical principle, tolerance is a particular 'virtue,' through which one is capable of critically seeing his/herself in a mutual-dependency to others. It is a modest, self-critical understanding of human limitations. The ground of tolerance as an ethical principle is the self-understanding of the limitations of men, who need others to cope with the limitations. Tolerance is ". . . a virtue that is closely allied with other virtues, such as modesty, generosity and hospitality" [12]. As a virtue, tolerance is not a passive indifference, but a positive value related to other values, which in a comprehensive way is capable of enriching human quality. Its basic wisdom is a respect for difference in an ethical community life.

As an ethical concept, tolerance is also a central concept in the discussion about pluralism. The idea of toleration could be seen as a condition for the possibility of pluralism: if one claims his-herself a pluralist, he/she should be committed to toleration. The basic idea of pluralism is that we have to acknowledge the plurality of the concept of good, which has its own claim of truth. But, when these plural claims meet one to another, they need mutual moral reflection and dialogue, the precondition of which is toleration: differences have to be tolerated in the condition that the related parties have to critically themselves in order to negotiate about what is the good and the true. Toleration is the only way in creating harmonious form of life that give space for us to work together in an attempt to come to a certain synthesis from the plural possibilities for good [12].

Tolerance is also a central concept in the discussion about 'multiculturalism'. Multiculturalism could be described as a tendency towards a recognition for the 'distance-less-ness' among different cultures, beyond national, religious, ethnic, or racial borders. It connotes a paradigm of constructing interdependence of cultural identities originated from two or more nationalities, which is seen as trans-national in their characters [13]. The difference between pluralism and multiculturalism is on the mode of recognition of differences. In pluralism, the central issue about difference is on recognitions of different culture, whereas in multiculturalism the central issue is on relations of difference between majority and minority, and possibilities for cultural mixing and hybridity.

In a more restricted dimension, multiculturalism is defined by Adams as a specific problem related to relations among different races in a state with white people population as the majority. In this condition, the main problem of multiculturalism is related to the issues about the absence of access, space or place for the existence and representation of other non-white races (black, yellow, red or brown), who are generalized as 'black' in a binary opposition model: black/white. Here, there is a kind of "great divide" between the white and the black (the generalized-reduced term to represent other races) [14]. In an almost similar tone, Habermas describes multiculturalism as a phenomena of immigrant people and immigrant culture, which were at the beginning tried to firmly define themselves in a frame of ethnicity in order to preserve certain elements of their traditions in a remote environment [15]. In the context of cultural representation, multiculturalism is described by Hall as a specific problem of 'politics of representation' or 'politics of position', which is politics in defining and constructing cultural identity beyond ethnic and cultural differences among different communities, in which there is a central problem of 'hegemony' of one identity to other identities [16].

'Difference' is one of the central concepts in the discourse about tolerance, both in the contexts of pluralism and multiculturalism. Yet, difference is not a single-unitary concept that represents a single phenomenon, but a continuously changing concept that represents a kind of 'spectrum of differences. In other words, there is a difference among differences themselves that could not be represented in a single-unitary concept. On one hand, there are static, retrospective and reproductive differences. On the other, there are dynamic, dynamic and productive differences. In addition, there is a substantial difference between the concept 'difference' and 'otherness'. While difference signifies the existence of two different but related entities, for example me and my friend without any mutual-relation or determination between them; 'otherness,' on the other hand, signifies the existence of two related entities, which have a relation of mutual-determination, for example a relation of man and woman: if there is no woman, there is no man either [17]

The concept of 'distance'-whether in social, political economic, cultural, or spiritual contexts - is another important concept in understanding tolerance, both in terms of pluralism and multiculturalism, particularly of what is called 'cultural distance'. It determines degrees of cohesiveness among related cultural elements. The distance determines closeness or distantness, integration or disintegration among elements of a society. Here, we have a concrete or physical distance, as a quantitative distance, which could be understood through a quantitative measurement. We also have a more abstract distance that is more qualitative in its nature, which could only be understood through a quantitative measurement [18]. 'Cultural distance' is this kind of abstract distance, which is a particular kind of distance in the cultural relations: a distance of 'value', 'belief', 'morality', 'taste', 'life-style' or 'meaning'. 'Inter-cultural communication' is one of the attempts to maintain a more moderate cultural distance in order to build a more balanced and symmetrical cultural relations [19].

The concept of 'foreigner' is one of the concept that is colesely related to cultural distance. This concept is often be defined in negative fashion. The foreigner is identified as beneficial or harmful at the same time, so that he/she is to be assimilated or rejected in a certain society. As remarked by Kristeva, facing the problem of the foreigner, ". . .the discourses, difficulties, or even the deadlocks of our predecessors do not only make up a history; they consitute a cultural distance that is to be preserved and developed, a distance on the basis of which one might temperand modify the simplictic attitudes of rejection or indifference, as well as the 
arbitrary or utilitarian decisions that today regulate relationships between foreigners" [20]. Reducing the cultural distance, therefore, is an important task of recent generations in order to create a more harmonious cultural life.

In terms of inter-cultural relations, distance is a signifier of cultural intimacy or distance, both in an abstract or concrete sense [18]. The intimacy in psychical, social or cultural senses is indicated by a degree of intimacy. In this context, 'intimacy' is understood as a process of giving interpersonal rewards characterized mainly by a mutual self-disclosure [21]. Different individuals or groups try to mutually disclose each other through the acknowledgement of all forms of exteriority as integral-unseparated parts of their interiority, their surrounding worlds as integral parts of their Umwelt [21]. One of the conditions of the increase of cultural distance is the waning of understanding of co-existence or living together among plural cultural groups. This is the effect of the robustness of egocentric sentiments, in which one's own Umwelt is regarded as the center of the world [19].

The waning of cultural distance is not only a signifier of egocentric sentiment, but also existential sentiment, which is the belief that traditions of a certain group are capable of producing a certain "cultural essentialism" as well as "biological essentialism", in which biological differences socially determines social behaviors [22]. Essentialism-as a celebration of self-essence as a sole owner of 'truth', 'virtue', 'the good' or 'honor' is the main source of all forms of exclusion, or worse, a demonization of others, which are accused as prima causa of all forms of failure, disorder, and uncertainty. This condition structurally obstructs inter-cultural communication among different ethnic, religious, racial, and national groups, as one main manifestations of the tolerant form of life [21].

\section{DISCUSSION AND RESULTS}

Discussions about tolerance in Indonesia could not be separated from discussions about the dynamics of political life, because of the strong determination of political power in shaping everyday life of the post-reformation society. At a level of ideology, Pancasila (The Five Ideological Principles) as a nation-state ideology - which emphasizes the communal and harmonious form of life, as a customary form of deliberation in the local democratic system [23] has been fundamentally eroded by the new political culture adopted from a more "liberal" model of democracy. Due to the strong determination of political power in shaping social life, the basic foundation of communal life has been fundamentally replaced by a more individualistic form of life.

The type of political culture initiated by the Founding Fathers is local in its character, extracted from various local values and wisdoms [24]. In contrast to modern political culture - which is strongly influenced by Western traditions of democracy - traditional political cultures in Indonesia has its roots from various ethnics, religions and other local cultures, which could be democratic or feudalistic. Nagari is an example of indigenous democratic political cultures practiced by Minangkabau ethnic group before it was abolished by the New Order, although it was revitalized during the Reformation Era. Unlike nagari, Javanese traditional political culture is more feudalistic in its nature, in which relations between the ruler and the ruled is a patron-client relationship, as it was practiced by Suharto [25].

One of the effect of reformation in 1998 is the change in the form of political contestation, which is much more individualistic. Since 1999 the formerly "collective image" or symbol of the competing parties were substituted by the "personal image" of individual candidates, in which personal image is more celebrated rather than personal capability or capacity. This transformation has radically changed the nature of the political culture itself, since the "personality" of the individual candidate has become more important as a basis of choosing a leader. To put the argument differently, the model of "popular culture" has became the mechanism in political contestation in choosing the leader. This made worst by the amandement of Constitution in 2002, which gave wider space for oligarchy, money poltics and the divide of society.

The climax of this social division was a series of Aksi Bela Islam (the Action to Defend Islam), one of which is known as Aksi 212 (the Action of 212), in 2016. The action was performed through mass mobilization of more than five million people, who demanded that Jakarta Governor Ahok should be jailed for blasphemy of a Qur'anic verse, as a moral construction on the "unity of Islamic ummat" to defend the Quran. The action was supported by the use of social media, and several Islamic forms of popular culture [26,27]. The 'great divide' has divided society into two opposite-conflicted groups: nationalist vs religious. The issue of radicalism that has been heralded by the nationalist to degrade the Islamic groups has made the conflicting situation worse, without any attempt to alleviate the conflict [28]. The "great divide" of society is a result of lack of anticipation of legislature who compile and revise the constitution that contains the conflicting and dividing effect in the society [29]. This amandement that was poorly prepared and discussed could be seen as a prime cause of the construction of an intoleranized-tolerant society of the post-reformation Indonesia.

In the above kind of society, art practice and art education could be one of alternative cultural strategies in re-shaping the ethically disintegrated, broken and divided society. Art education has to take part in finding a certain way to strengthen tolerance in society in general, instead of being trapped in the trap of intolerance. At the level of philosophical discourse, there have been several philosophical ideas related to the contemporary model of social relation and how they are relevant in the discussion about tolerance. 'Transculturality' is one of these ideas, to describe a complex interconnection and intersection of different cultures in a common space as the consequence of the increasing complexity in society, the network society that is striving for social networking, and the crossing between two or more cultures that creates a cultural hybrid [30]. Based on this argument, it could be argued 
furthermore that the trans-cultural capacity is one of the basic capacities in the dialogue, exchange, and intersection between cultures, through which a new cultural form could be creatively generated.

In an attempt to straighten tolerance through art practice and art education, it is important to consider tolerance in terms of its 'locus', that is, the 'location' in or through which the spirit of tolerance is substantially built. In this sense, an attempt to strengthen tolerance could be performed in three main areas: 1) tolerance through art process, 2) tolerance through art event, and 3) tolerance in art work.

First, the spirit of tolerance could be built in the art process itself, in which various artists from different ethnic, racial, religious, ideological and artistic background could be inclusively and constructively conditioned to work together or collaborate in a certain artistic collaboration. In terms of epistemology, art education could be conducted through what is recently called a trans-disciplinary model of knowledge production. In trans-discipline, several disciplines work together in a situation that there are intersections between disciplines. It is an attempt to construct common methods, concepts or theories; to cross the boundaries between disciplines, to synthesize common insight to perform a mutual learning, or to share common information or knowledge [30]. It is ". . . a new form of learning and problem-solving involving cooperation among different parts of society and academia in order to meet complex challenges of society" [31].

Transdisciplinary is a logical consequence of the emergence of 'dialogism' as a recent model of social production, in which knowledge and ideas are dominantly produced through the mechanism of dialogue, for instance through a mechanism of brainstorming in the Internet [32]. It is a dynamic way of knowledge production and ideas generation, through mechanisms of intersubjective relation, knowledge linkage, cognitive dialogue, intensive participation, and mutual understanding, in order to intensify the exchange of ideas and the accumulation of knowledge [33]. 'Co-creation' is an essential mechanism in transdisciplinary, as a mechanism in accumulating positive energies for all experts involved in certain activity of idea's generation or problem solving [34], and ". . . an active, creative, and social collaboration process linking producers and consumers, aided by the organization" [35]. It is collaborative, inclusive and dialogical characters that make transdisciplinarity a potential way in creating and strengthening tolerance.

Second, the spirit of tolerance could be built through art event, through which people from different ethnic, racial, religious, disciplinary and subcultural groups are able to inclusively and openly work together in various art events: exhibitions, festivals, carnivals, shows or expositions. In various local-ethnic based festivals, the basic principle of gotong royong is generally adopted as a working model of the art communities. Gotong royong is a means to work together, help each other, and provide mutual support that could be appropriated in the context of art collaboration. This model of work together has to be reinterpreted in a contemporary society, which is no longer paguyuban in its character, in the conventional sense of the term [36]. Jember Fashion Carnival (JFC) is an example of reinterpretation of work together. As an art festival it is a medium in constructing inclusive and tolerant society, a multicultural society, which cannot be separated from the root of Jember as a multicultural region, where the mix of Madurese and Javanese had created a culture of pedalungan, which is a mix and inclusive culture of Jember [37].

Third, the spirit of tolerance could be represented in art event, in which the value of openness, inclusivity and tolerance is the main theme of art works. This is because one of the main functions of art is an ideological function, which is the function of representing a certain idea. Here, art is an ideological activity and ideological product. According to Wolff, "...the ideas and values of artist, themselves socially formed, are mediated by literary and cultural conventions of style, language, genre and aesthetic vocabulary [38]. Several works of Garin Nugroho could be seen in the frame of this ideological representation. In Moon Cake Story (1990), for example, Garin constructed the message about tolerance in the film. The message of tolerance is represented in two main and opposite characters in the film: a Javanese poor girl (Asih) and Chinese rich businessman, who are involved in various inclusive and mutual-respects. The main message of the film is the spirit of "difference for sharing", as a deep message about the spirit of tolerance [39]

The three loci of tolerance have to be posited properly in the very structure of art and design education, particularly in three aspects of recent art and design education: curriculum development, theoretical basis, and art and design practice. At the level of curriculum, the multicultural-based curriculum has to be developed, in which tolerance is one of its central issue and problem. Therefore, the curriculum has to be inclusive in its character, in which there are enough spaces for different cultural values to be part of inclusive and dynamic academic discourse. The curriculum has also to be holistic, in which the parts have to be discussed from the point of view of the whole. At the theoretical level, it is important to develop dynamic theoretical knowledge that encourages better understanding of tolerance, pluralism and multiculturalism: theories of difference, otherness, dialogism, and inter-cultural communication. At the level of art and design practice, three loci of tolerance could be posited as central principle of the practice: tolerance in art process, tolerance through art process and tolerance in art work.

\section{CONCLUSION}

As discussed previously, the process of political reformation and democratization at the end of 1998s have some profound impacts to the whole social life, particularly to the model of social relation, the role of political power in shaping the relations, the effect of political power in creating a kind of intoleranized-tolerant society. Here, the deep intervention of political power to everyday life, has created a deeper gap and "cultural distance" between different ethnic, racial and religious 
groups, which has been crystallized in a kind of "great divide", which divides society into two conflicting groups. Rethinking about the role of Art and Design Education in strengthening tolerance aims to bridge this gap and 'distance' by highlighting the role of art within a critically based approach to art and design education that promote tolerance in a multicultural society.

The role of art and design education in strengthening the spirit of tolerance could not be performed partially on the basis of a certain artistic or design scope, but on the more comprehensive and holistic approach to art and design education, which sees art and design as a process, event and product. Here, an attempt to strengthen tolerance through art and design could be manifested in three models. First, the spirit of tolerance could be built in the art or design process itself, in which artists or designers from different ethnic, racial and religious backgrounds could work together in collaborative and transdisciplinary models. Second, the spirit of tolerance could be built through art and design events (exhibitions, festivals, carnivals, etc.), through which several individual or groups of artists or designers create an event on the basis of multicultural value. Third, the spirit of tolerance could be represented in art and design works themselves, through which the readers, spectators or users of art and design works are capable of reflecting and contemplating the message of tolerance within the works.

\section{REFERENCES}

[1] J.L. Nancy, Being Singular Plural. Stanford: Stanford University Press, 2000 , p. 185

[2] Subagyo, "Pengembangan Nilai dan Tradisi Gotong Royong dalam Bingkai Konservasi Nilai Budaya," Indonesian Journal of Conservation, Vol. 1, No. 1, pp. 61-68, Juni 2012.

[3] Koentjaraningrat, Kebudayaan Mentalitas dan Pembangunan. Jakarta: Gramedia, 1974, p. 60

[4] N. Mulder, Pribadi dan Masyarakat di Jawa. Jakarta: Penerbit Sinar Harapan, 1985, p. 51

[5] S. Arif, Falsafah Kebudayaan Pancasila: Nilai dan Kontradiksi Sosialnya. Jakarta: Penerbit PT Gramedia Pustaka Utama, 2016, p. 106

[6] H.I. Hakimy Dt. Rajo Penghulu, Rangkaian Mustika Adat Basandi Syarak di Minangkabau. Bandung: CV Remaja Karya, 1984, p. 89.

[7] F. Suleman, "Keberagaman Budaya dan Agama di Kota Manado", Endogami: Jurnal Ilmiah Kajian Antropologi, vol. 1, no. 1, pp. 55-62, 2017

[8] Y.G. Malatuny and S.P. Ritiauw, "Eksistensi Pela Gandong Sebagai Civic Culture dalam Menjaga Harmonisasi Masyarakat di Maluku", Sosio Didaktika: Social Science Education Journal, Vol. 5, no. 2, pp. 3546, 2018.

[9] F. Fadli, "Media Kreatif Walisongo Dalam Menyemai Sikap Tolerans Antar Umat Beragama di Jawa", Al-Tadzkiyyah: Jurnal Pendidikan Islam, Vol. 10, No. 2, pp. 287-302, 2019.

[10] H. Idrus Hakimy Dt. Rajo Penghulu, Rangkaian Mustika Adat Basandi Syarak di Minangkabau. Bandung: CV Remaja Karya, 1984.

[11] Supatmo and Syafii, "Nilai Multikultural Ornamen Tradisional MasjidMasjid Warisan Para Wali di Pesisir Utara Jawa", Jurnal Imajinasi, Vol. 13, No. 2, pp. 2-14, 2019
[12] A. Fiala, Tolerance and the Ethical Life. London: Continuum, 2005, p.1.

[13] M, Payne, A Dictionary of Cultural and Critical Theory. Oxford: Basil Blackwell, 1998, p. 353

[14] M.V. Adams, The Multicultural Imagination: Race, Color, and the Unconscious. London: Routledge, 1996, p. 23.

[15] J. Habermas, The Inclusion of the Other: Studies in Political Theory, The MIT Press, 1999, p. 223.

[16] S. Hall, 'New Ethnicity', dalam Davis Morley (ed), Stuart Hall: Critical Dialogues in Cultural Studies. London: Routlesge, 1996, p. 441.

[17] M. deBeistequi, Truth \& Genesis: Philosophy as Differential Ontology, p 49.

[18] E.T. Hall, The Hidden Dimension, Anchor Book, 1969

[19] Edward E. Sampson, Celebrating The Other: A Dialogic Account of Human Nature, Harvester Wheatsheaft, London, 1993, hlm. 3

[20] J. Kristeva, Strangers to Ourselves. New York: Columbia University Press, 1991, p. 95-104

[21] S.Ting-Toomey and F.Korenny, Cross-cultural Interpersonal Communication. London: Sage Publication, 1991, p. 164

[22] J. Young, The Exclusive Society, pp. 105.

[23] S. Arif, Falsafah kebudayaan Pancasila: nilai dan kontradiksi sosialnya Jakarta: Penerbit PT Gramedia Pustaka Utama, 2016, pp. 106.

[24] J. Utama, Berpikir ulang tentang keindonesiaan. Jakarta: Penerbit Buku Kompas, 2001, p. 5

[25] K. Marijan, Sistem politik Indonesia: konsolidasi demokrasi pasca-Orde Baru. Jakarta: Prenada Media Group, 2015, p. 129

[26] A.S. Pamungkas and G. Octaviani, "Aksi bela Islam dan ruang publik muslim: dari representasi daring ke komunitas luring," In Jurnal Pemikiran Sosiologi, vol. 4, no. 2, pp. 65-87, 2017.

[27] M. Wildan, "Aksi damai 411-212, kesalehan popular, dan identitas muslim perkotaan Indonesia," In Journal Maarif, vol. 11, no. 2, pp. 188202,2016

[28] A.G. Herdiansah and H. Ismiati, "Pembelahan Ideologi, Kontestasi Pemilu, dan Persepsi Ancaman Keamanan Nasional: Spektrum Politik Indonesia Pasca 2014?," Jurnal Wacana Politik, Vol. 2, No. 1, pp. 61 73, 2017.

[29] DetikNews, 26th March 2019

[30] Wolfgang Berg (ed), Exploring Transculturalism: A Biographical Approach, VS Research, Heildelberg, 2010, p.10

[31] Charles Kleiber in J. Thompson Klein et.al., Transdisciplinarity: Joint Problem Solving Among Science, Technology and Society, Springer Basel AG, Basel, 2001, p. 6

[32] M. Cockell, Common Knowledge: Tha Challenge of Transdisciplinarity, EPFL Press, Lausanne, 2011, p. xiii

[33] P. Lévy, "Towards a Science of Collective Intelligence", in Cockell, $p$. 167

[34] Hasso Plattner et.al., Design Thinking Research: Studying Co-Creation in Practice, Heidelberg: Springer, 2012, p.1

[35] K.B. Akhilesh, Co-Creation and Learning: Concepts and Cases, Heidelberg: Springer, 2017, p.3

[36] Subagyo, Indonesian Journal of Conservation, p.116

[37] R. Jannah, "Jember Fashion Carnaval: Konstruksi Identitas dalam Masyarakat Jaringan", Jurnal Sosiologi Masyarakat, Vol. 12, No. 2, pp.135-151, 2018.

[38] J. Wolff, The Social Production of Art. London: The MacMillan Press Ltd., 1981, p. 65

[39] Republika, 21 th March 2017 